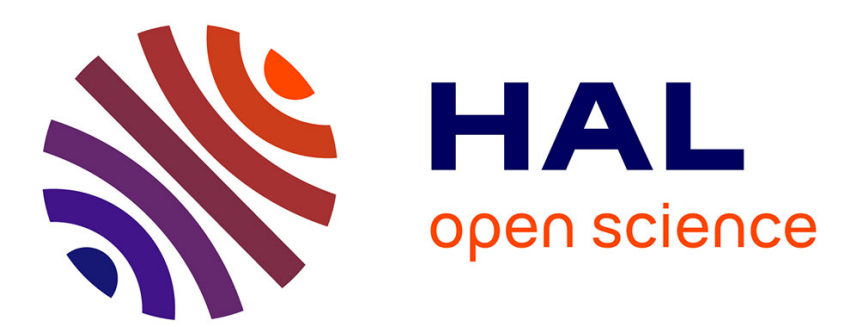

\title{
Computer modelling of plasticity in minerals - The hydrolytic weakening of quartz
}

M. Heggie, R. Jones

\section{To cite this version:}

M. Heggie, R. Jones. Computer modelling of plasticity in minerals - The hydrolytic weakening of quartz. Revue de Physique Appliquée, 1988, 23 (4), pp.670-670. 10.1051/rphysap:01988002304067000 . jpa-00245819

\section{HAL Id: jpa-00245819 https://hal.science/jpa-00245819}

Submitted on 1 Jan 1988

HAL is a multi-disciplinary open access archive for the deposit and dissemination of scientific research documents, whether they are published or not. The documents may come from teaching and research institutions in France or abroad, or from public or private research centers.
L'archive ouverte pluridisciplinaire HAL, est destinée au dépôt et à la diffusion de documents scientifiques de niveau recherche, publiés ou non, émanant des établissements d'enseignement et de recherche français ou étrangers, des laboratoires publics ou privés. 
COMPUTER MODELLING OF PLASTICITY IN MINERALS

- THE HYDROLYTIC WEAKENING OF QUARTZ

M. Heggie and R. Jones, Dept. of Physics, University of Exeter, Devon EX4 $4 \mathrm{QL}, \mathrm{GB}$.

In the two decades since the hydrolytic weakening effect in quartz was observed in the laboratory $/ 1 /$, there has been a consistent effort, firstly, to identify the water-related weakening agent and, secondly, to establish whether this agent primarily affects dislocation mobility or dislocation density. The experimental situation is still uncertain and has been extensively reviewed elsewhere $/ 2,3,4,5,6 /$, but by means of atomistic computer modelling we have obtained some evidence for the identity of the water-related species and for a mechanism by which it can increase dislocation mobility $/ 7,8 /$.

Our method was first to find a potential function that could reasonably describe the elastic, phonon and internal strain properties of the perfect $\alpha-$ quartz structure $19,10 /$. This potential function was based on a covalent description of the $\mathrm{SiO}_{2}$ network: the energy of $\mathrm{Si}$ and $\mathrm{O}$ atoms depending on Si-O and O-O lengths and Si-O-Si and O-Si-O angles. With the potential we could calculate the energy of distorted $\mathrm{SiO}_{2}$ structures, providing there were no broken bonds. We could also estimate the relative energies of water and hydroxyl groups in different configurations in the $\mathrm{SiO}_{2}$ network by regarding the hydrogen as merely saturating oxygen dangling bonds and arguing that the energy of each $\mathrm{O}-\mathrm{H}$ bond should be more-or-less independent of its environment.

With this potential we found the structure of perfect dislocations in $\alpha$-quartz with low energy cores $19,10 /$ and then looked at kink pair nucleation and migration on one of them. The dislocation had Burgers vector $a_{1}$ and line direction $a_{2}$ (referring to hexagonal lattice vectors) and was labelled $\mathrm{B} 60 \mathrm{a}$. The lowest energy structure for the core was labelled $\mathrm{H} 3 \mathrm{C} 4$ and it had a core energy of $3.0 \mathrm{eV}$ for a core radius of $7.4 \AA$. The kink nucleation energy was about $5 \mathrm{eV}$ and it was independent of kink separation, within the accuracy of our determination. A rough estimate of the migration energy gave a minimum value of $4.2 \mathrm{eV}$. Very approximate values for these energies have been obtained experimentally from dislocation motion around crack tips in dry quartz /3/ - they are about $3 \mathrm{eV}$ for nucleation and $6 \mathrm{eV}$ for migration, comparable with our estimates.

In wet quartz the possibility had been suggested $111 /$ that water could act like a dopant in a semiconductor and that kink nucleation and migration energies would be lowered by charge transfer. However, we were unable to find a credible water- related structure that could act in this fashion $/ 8 /$. It turned out that the original hypothesis /1/ of $\equiv$ Si-O-Si $\equiv$ being hydrolysed to

$\equiv \mathrm{Si}-\mathrm{OH} \mathrm{HO}-\mathrm{Si} \equiv$ was more likely, reducing the kink pair nucleation energy to between 2 and $3 \mathrm{ev}$. The reason for this large drop was the release of strain in the kink pair caused by cutting a very stretched bond. More elaborate mechanisms for kink pair nucleation involving non-abrupt kinks and allowing the hydroxyl groups to separate led to a further lowering of the kink pair nucleation energy to less than $1 \mathrm{eV}$.

Similar results were also obtained for MacLaren's model of the water defect $/ 12 /$, which can be thought of either as $2 \mathrm{H}_{2} \mathrm{O}$ molecules replacing one $\mathrm{SiO}_{2}$ formula unit or $4 \mathrm{H}$ atoms replacing one silicon atom, i.e. (4H) Si. Our conclusion was that both localised, hydrolysis models due to Griggs / $/$ and to Maclaren et al /12/ could be responsible for hydrolytic weakening, through a profound increase in dislocation mobility.

Finally, it should be noted that our original calculations with the phenomenological potential function have been reinforced by ab-initio, local density functional calculations of $\equiv$ Si-O-Si $\equiv$ hydrolysis and the subsequent interaction of hydroxyl groups $/ 8 /$.

\section{References}

11/ D. T. Griggs, J. D. Blacic, Science, 147, 292, 1965

/2/ J. D. Blacic, J. M. Christie, J. Geophys. Res., $89,4223,1984$

13/ J-C. Doukhan, L. Trepied, Bull. Minéral., 108, 97, 1985

141 B. E. Hobbs, Tectonophysics, 78, 335, 1981.

/5/ S. H. Kirby, J. Geophys. Res., 85, 6353, 1980.

16/ M. S. Paterson, "Dislocations and Properties of Real Materials", (London: The Metals Society), 1984

/7/ M. Heggie, R. Jones, Phil. Mag. A, 53, L65, 1986.

/8/ M. Heggie, R. Jones, Phil. Mag. Letters, 55, 47,1987

/9/ M Heggie, M Nylén, Phil. Mag. B, 50, 543, 1984.

/10/M. Heggie, M. Nylén, Phil. Mag. B, 51, L69, 1985.

/11/ P. B. Hirsch, J. de Physique, 42, C3-C149, 1981.

/12/ A. C. Maclaren, R. F. Cook, S. T. Hyde, R. C. Tobin, Phys. Chem. Minerals, 9, 79, 1983. 